\title{
Vybrané charakteristiky vnútorného zat’aženia elitných mladých futbalistov v prípravných hrách s rôznymi parametrami
}

\section{Internal load of youth elite soccer players in various small-sided games}

\author{
Pavol Peráček', Matúš Bôžik², Martin Mikulič' \\ 1 Fakulta telesnej výchovy a športu Univerzity Komenského, Slovensko, Faculty of Physical Education and Sport, \\ Commenius University, Slovakia \\ 2 Selangor State Development Corporation Football Club, Malaysia \\ pavol.peráček@uniba.sk,matusbozik@gmail.com,martin.mikulic@uniba.sk
}

\begin{abstract}
Abstrakt
Cielom práce bolo rozširit' poznatky o vnútornom zatažení elitných mladých hráčov vo futbale v prípravných hrách s rôznymi parametrami v kategórii do 15 rokov. Súbor tvorilo 16 elitných futbalistov. Družstvo bolo účastníkom 1. slovenskej ligy. Zistovali sme čas, ktorý absolvujú hráči v bioenergetických zónach zat’aženia (\% z maximálnej SF), v prípravných hrách s počtom hráčov 2:2, 3:3 a rozmermi ihriska $25 \times 18$ metrov a $30 \times 25$ metrov. V práci sme využili základné matematicko-štatistické charakteristiky a Wilcoxonov t-test pre neparametrické výbery. Zistili sme, že v kategórii do 15 rokov platí, že väčší počet hráčov (3:3) v prípravných hrách, indikuje menej času, ktorý hráči absolvujú v bioenergetických zónach 4 a 5. Nepriama úmera platí aj pri rozmeroch ihriska, v závislosti od času stráveného v zátažových zónach č. 4 a 5. Tzn., že ak zväčšíme rozmery ihriska, hráči strávia kratší čas v zónach, ktoré sú pre nás tažiskové. Väčší rozmer ihriska spôsobuje menej času, ktorý hráči strávia v bioenergetických zátažových zónach. Ak chceme využit prípravné hry ako komplexný tréningový prostriedok v rámci herného tréningu, musíme brat naše zistenia pri plánovaní tréningového procesu a jeho realizácii do úvahy.
\end{abstract}

Klíčová slova: futbal, vnútorné zat’aženie, srdcová frekvencia, prípravné hry, kategória do 15 rokov

\begin{abstract}
The main aim of the study was to find more information about the internal load of elite young soccer players in small-sided games with different parameters. The group consisted of elite soccer players $(n=16)$ in under 15 years category. The team participated in the 1st Slovak league. We've tracked the time spent by players in selected bioenergetics load zones (\% of maximum HR) during small-sided games with 2:2, 3:3 players and $25 \times 18$-meter and $30 \times 25$-meter playing field. We used the basic mathematical-statistical characteristics and Wilcoxon t-test for non-parametric selections. We found that in the category under 15 years, a larger number of players (3:3) in the small-sided games indicates less time spent in bio-energy zones 4. and 5. Indirect intentions also apply to the dimensions of the playing field, depending on the time spent in load zones no. 4. and 5. That means that the larger the size of the playing field causes less time spent by players in bio-energy load zones that are imported to us. If we want to use them as a comprehensive training tool (game training), this is what we consider to be an adequate training tool.
\end{abstract}

Key words: soccer, internal load, heart rate, small-sided games, category under 15 years 


\section{ÚVOD}

Vo futbale existuje množstvo technických prostriedkov a rôznych sofistikovaných systémov, ktoré nám umožňujú dokonalejšie analyzovat zataženie hráča v tréningu i v zápase (Catapult, InStat, Panini, Prozone, LPM Soccer 3D). Prostredníctvom týchto softwarov vieme získat množstvo premenných, ktoré ovplyvnujú herný výkon. Preto ich musíme selektovat a extrahovat len tie relevantné. Tréneri by ich mali využit a implementovat do tréningového procesu. Dôležitou súčastou tréningového procesu je jeho plánovanie, ktoré je zamerané na optimálny rast športovej výkonnosti. Treba však poznat̉ zákonitosti tréningového zataženia. Tzn., že zataž (tréningový podnet)- stresor musí byt' adekvátny, aby nastali adekvátne adaptačné zmeny v organizme hráča (Bada, 2014). Jeden tréningový podnet pri určitej intenzite sa stáva účinným len pri dosiahnutí príslušného objemu. To neplatí iba pre oblast rozvoja pohybových schopností, ale taktiež to platí pre oblast' zdokonalovania technickej stránky herných činností. Iba pri optimálnom počte opakovaní sa upevňuje pohybová koordinácia, ktorá sa vyznačuje ideálnym priebehom pohybovej činnosti (Holienka, 2005).

V práci sme sa snažili získat informácie o vnútornom zatažení hráčov v rozličných prípravných hrách s rôznymi parametrami a $\mathrm{v}$ akých bioenergetických režimoch práce a ako dlho hráči pracovali. Týmto smerom by sa mali orientovat budúce výskumy (Hill-Haas, 2011). Prostredníctvom prípravnej hry dosiahneme zdokonalenie a stabilizáciu herných činností jednotlivca (Gabbett, Jenkins, \& Abernethy, 2009), ich technickej stránky (Gabbett, 2006) a v neposlednom rade rozvoj tvorivého potenciálu hráča (Gamble 2004, Owen 2003, Gregson \& Drust, 2000; Little, 2009). Podmienky v PH umožňujú tvorit rozmanité retazce herných činností a herných kombinácií, pozitívne pôsobiacich na orientáciu hráčov v priestore, ich aktivitu a taktiež emocionálnost' (Gregson \& Drust, 2000; Little, 2009). Či už tréningové alebo zápasové zataženie má rozhodujúcu úlohu ako adaptačný podnet. Jednorazové zataženie spôsobí jednorazový tréningový efekt. Správne, vhodné a opakované zataženie $\mathrm{v}$ tréningovom procese prináša kumulatívny tréningový efekt. Musíme tiež rešpektovat genetickú podmienenost hráčov premietajúcu sa do individuálnej reakcie organizmu na aplikované zataženie (Holienka et al., 2012). Adaptácia je dôsledkom opakujúcich sa zložitých podnetov, zmenšenie reakcie organizmu na dané podnety. Podmieňuje ekonomickejšiu prácu tiež vyšší výkon. Z psychologického a sociologického hl'adiska chápeme tento proces ako vytváranie určitých vztahov medzi osobnostou a prostredím. „Adaptácia je proces aj výsledok“ (Peráček, 2001).

Protirečivý charakter hry núti hráčov rýchlo prepínat z útočných činností na obranné a naopak, čím sa rozvíjajú ich momentálne univerzálne herné schopnosti. Táto schopnost hráčov je úmyselne stimulovaná práve počas rôznych prípravných hier, kedy sa hráči musia vyrovnat s časovým a priestorovým tlakom, ktorý na nich vyvíja súper (Engel et al., 2016). Adekvátnym obmeňovaním pravidiel a obsahu PH plníme rôzne ciele a úlohy. PH na rozdiel od HC majú monolitný herný dej (Peráček, 2004). V tejto vekovej kategórii, dochádza k zlepšeniu sa učenia a pri nácviku a zdokonal'ovaní určitých herných činností sa znižuje množstvo opakovania nutné k úspešnému zvládnutiu hernej úlohy. Motorický i senzomotorický vývoj sa blíži k svojej finálnej podobe (Vilímová, 2002).

\section{METODIKA}

Ciel’om práce je získat poznatky o vybraných charakteristikách vnútorného zataženia futbalistov $\mathrm{v}$ prípravných hrách s rôznymi parametrami. Výskumný súbor tvorilo 16 elitných hráčov v kategórii do pätnást’ rokov s priemernou telesnou výškou $171,5 \pm 14,5 \mathrm{~cm}$ a priemernou telesnou 
hmotnostou $58,1 \mathrm{~kg} \pm 15 \mathrm{~kg}$. Družstvo je účastníkom 1 . slovenskej celoštátnej futbalovej ligy kategórii do 15 rokov.

Na základe testu Bensona \& Connollyho (2012) sme zistili maximálnu srdcovú frekvenciu hráčov. Následne sme pomocou softwaru Polar Team 2 Pro analyzovali srdcovú frekvenciu hráčov počas trvania $\mathrm{PH}$. Určili sme si jednotlivé zóny z maximálnej srdcovej frekvencie hráčov.

Použili sme Wilcoxonov t-test pre neparametrické súbory, na posúdenie vplyvu efektu počtu hráčov a rozmerov prípravných hier na čas strávený v bioenergetických zátažových zónach (zóna 4. 85-95\% SFmax a zóna 5. 96-100\% SFmax.) sme použili Effect size podl'a Cohena (d). Všetky štatistické hypotézy boli posudzované na hladine významnosti $\mathrm{p}<0,05$. Táto štúdia bola schválená Etickou komisiou Fakulty telesnej výchovy a športu Univerzity Komenského v Bratislave.

$$
\begin{aligned}
& \mathrm{S}_{1}\left(\mathrm{R}_{1}\right) \leftrightarrow \mathrm{S}_{1}\left(\mathrm{R}_{2}\right) \\
& \mathrm{S}_{2}\left(\mathrm{R}_{1}\right) \leftrightarrow \mathrm{S}_{2}\left(\mathrm{R}_{2}\right) \\
& \mathrm{R}_{1}\left(\mathrm{~S}_{1}\right) \leftrightarrow \mathrm{R}_{2}\left(\mathrm{~S}_{1}\right) \\
& \mathrm{R}_{1}\left(\mathrm{~S}_{2}\right) \leftrightarrow \mathrm{R}_{2}\left(\mathrm{~S}_{2}\right)
\end{aligned}
$$

$S_{1}-2: 2$ (štyria hráči s výnimkou brankárov)

$\mathrm{S}_{2}-3: 3$ (šiesti hráči s výnimkou brankárov)

$\mathrm{R}_{1}-25 \times 18$ metrov

$\mathrm{R}_{2}-30 \times 25$ metrov

\section{HYPOTÉZY}

H1. So zmenou rozmerov ihriska $(\mathrm{R} 1, \mathrm{R} 2)$ zaznamenáme významný rozdiel v trvaní časového úseku, ktorý hráči strávia v ciel’ových bioenergetických zónach 4 (85-95\% SFmax) a 5 (96-100\% SFmax).

H2. So zmenou počtu participujúcich hráčov $(\mathrm{S} 1, \mathrm{~S} 2)$ zaznamenáme významný rozdiel v trvaní časového úseku, ktorý hráči strávia v ciel’ových bioenergetických zónach 4 (85-95\% SFmax) a 5 (96-100\% SFmax).

\section{PRIEBEH VÝSKUMU}

Výskumná situácia predstavovala meranie srdcovej frekvencie futbalistov počas šiestich opakovaní v prípravných hrách $2: 2$ a 3:3 s rozmermi ihriska $25 \times 18 \mathrm{~m}$. Sledovali sme dížku časového úseku, ktorý hráči absolvujú $\mathrm{v}$ určených zónach tréningového zataženia. Interval tréningového zataženia bol 2 minúty. Interval odpočinku medzi opakovaniami bol 4 minúty. Počet opakovaní bol šest̉ v oboch PH. Hráčov sme inštruovali o pravidlách PH (hráči nemôžu prihrat svojmu brankárovi, družstvo od ktorého sa lopta dostane za vymedzený priestor, stráca loptu a začína súper od brankára). 




Obr. 1 Príklad PH 2:2-25×18m $(30 \times 25 \mathrm{~m})$

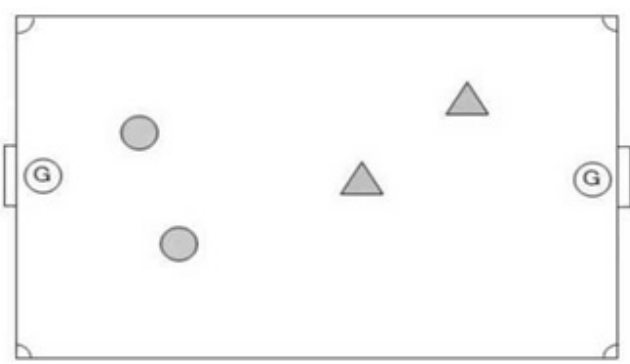

Obr. 2 Príklad PH 3:3-25×18m

$(30 \times 25 \mathrm{~m})$

Hodnoty srdcovej frekvencie hráčov sme zapisovali do zberného hárku (Tab. 1).

Tab. 1: Zberný hárok na zaznamenávanie SF

\begin{tabular}{|l|l|l|l|l|l|l|l|l|l|l|l|}
\hline \multicolumn{1}{|c|}{ PH } & SFmax & \multicolumn{8}{c|}{ Čas v zónach (s, \%) } \\
\hline $25 \times 18 \mathrm{~m}$ & & \multicolumn{2}{|c|}{$0-62 \%$} & \multicolumn{2}{c|}{$63-73 \%$} & \multicolumn{2}{c|}{$74-84 \%$} & \multicolumn{2}{c|}{85 \% $\%$} & \multicolumn{2}{c|}{$96-100 \%$} \\
\hline & & Čas & Percentá & Čas & Percentá & Čas & Percentá & Ćas & Percentá & Ćas & Percentá \\
\hline 1. opak. & & & & & & & & & & & \\
\hline 2. opak. & & & & & & & & & & & \\
\hline 3. opak. & & & & & & & & & & & \\
\hline 4. opak. & & & & & & & & & & & \\
\hline 5. opak. & & & & & & & & & & & \\
\hline 6. opak. & & & & & & & & & & & \\
\hline Spolu & & & & & & & & & & & \\
\hline Priemer & & & & & & & & & & & \\
\hline
\end{tabular}

\section{VÝSLEDKY}

Komparácia PH 2:2 s rôznym rozmermi ihriska nám indikuje fakt, že menší rozmer ihriska $(25 \times 18 \mathrm{~m})$ pôsobí na zataženie hráčov intenzívnejšie, resp. hráči absolvujú v bioenergetickej zóne 5 (96-100 \% SF max) dlhší časový úsek (43,61 \% z celkového času), počas ktorého sa PH hrala.

Pre tréningový proces sú z pohl’adu intenzifikácie tréningového procesu tažiskové bioenergetické zóny 4. a 5. Môžeme ich chápat ako herný tréning (súbežný tlak na zručnostný a zdatnostný potenciál). Porovnanie súčtu zaznamenaných časových úsekov tréningového zataženia $\mathrm{v}$ zónach 4. a 5. určuje prípravnú hru s rozmerom ihriska $25 \times 18$ metrov ako efektívnejšiu, pretože hráči počas nej strávia o $4,1 \%$ času viac v uvedených zónach ako v PH s rozmermi $30 \times 25$ metrov. Tento záver sme potvrdili aj pomocou Cohenovho d, kedy miera účinku vel'kosti ihriska dosiahla hodnotu $\mathrm{d}=0,752$, čo znamená hornú hranicu stredného efektu. Môžeme tvrdit, že PH 2:2 s rozmerom $25 \times 18$ metrov je efektívnejšia z pohl'adu dosiahnutého tréningového zataženia.

Tab. 2: Komparácia PH 2:2 s rôznymi rozmermi ihriska

\begin{tabular}{|c|c|c|c|c|c|}
\hline Rozmer PH 2:2 & 1. zóna & 2. zóna & 3. zóna & 4. zóna & 5. zóna \\
\hline $25 \times 18 \mathrm{~m}$ & $1,49 \%$ & $8,85 \%$ & $11,48 \%$ & $34,57 \%$ & $43,61 \%$ \\
\hline $30 \times 25 \mathrm{~m}$ & $1,46 \%$ & $10,24 \%$ & $14,22 \%$ & $42,92 \%$ & $31,16 \%$ \\
\hline
\end{tabular}




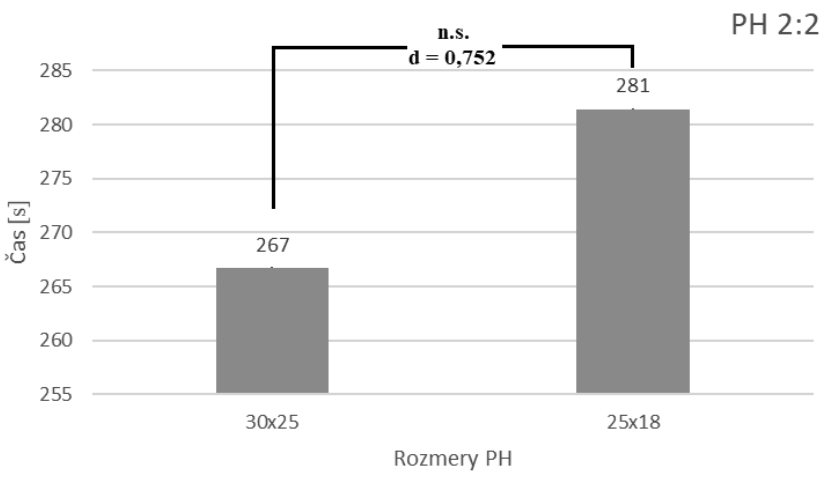

Obr. 3 Komparácia PH 2:2 s rôznymi rozmermi ihriska

Komparácia prípravných hier s počtom hráčov $3: 3$, s rôznymi rozmermi (R1,R2), nám určila obdobný výsledok ako PH $2: 2$. V PH s rozmerom $25 \times 18 \mathrm{~m}$, hráči vykonávali herné činnosti v zátažovej zóne 5 o takmer 11 \% dlhší čas ako v PH s rozmermi $30 \times 25$ metrov. Celkový časový úsek v zónach 4. a 5. pri menšom rozmere ihriska $P H$, predstavoval hodnotu o takmer $9 \%$ vyššiu. Štatistická významnost’ nebola potvrdená, ale vecnú významnost’ sme potvrdili stredným účinkom Effect size $(\mathrm{d}=0,626)$. Znamená to, že môžeme tvrdit, že $\mathrm{PH} 3: 3 \mathrm{~s}$ rozmerom $25 \times 18$ metrov je efektívnejšia z pohl'adu teórie adekvátneho krytia dosiahnutého tréningového zataženia.

Tab. 3: Komparácia PH 3:3 s rôznymi rozmermi ihriska

\begin{tabular}{|c|c|c|c|c|c|}
\hline Rozmer PH 3:3 & 1. zóna & 2. zóna & 3. zóna & 4. zóna & 5. zóna \\
\hline $25 \times 18 \mathrm{~m}$ & $1,76 \%$ & $6,16 \%$ & $10,74 \%$ & $54,26 \%$ & $27,08 \%$ \\
\hline $30 \times 25 \mathrm{~m}$ & $1,06 \%$ & $7,31 \%$ & $19,19 \%$ & $56,11 \%$ & $16,32 \%$ \\
\hline
\end{tabular}

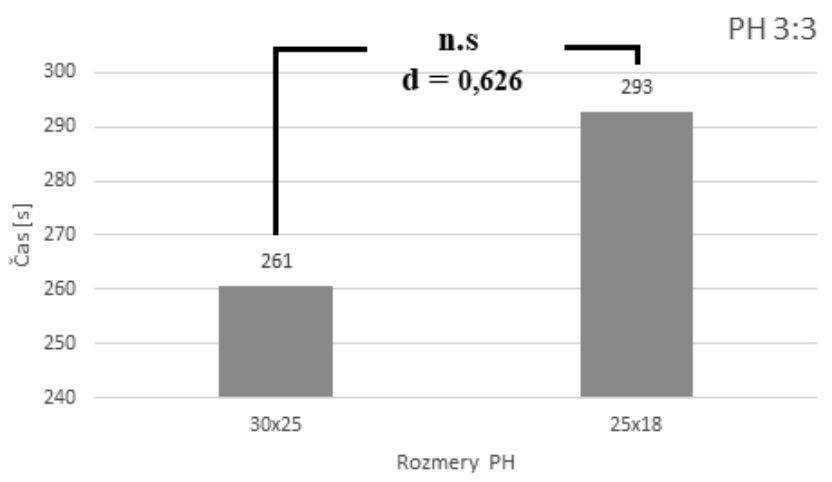

Obr. 4 Komparácia PH 3:3 s rôznymi rozmermi ihriska

Ak porovnáme PH 3:3 s PH 2:2, pri rovnakých rozmeroch ihriska $(25 \times 18 \mathrm{~m})$, z hladiska intenzity zataženia je efektívnejšia PH s väčším počtom hráčov ( $3: 3)$. Pretože v súčte časového úseku tréningového zataženia v klúčových zónach č. 4 a č. 5 hráči absolvovali o 3,16 \% času viac $\mathrm{v}$ porovnaní s PH s menším počtom hráčov. Z pohl'adu intenzity tréningového zataženia sa však prejavuje PH s menším počtov hráčov ako efektívnejšia (n.s), pretože hráči strávili dlhší časový úsek v najintenzívnejšej zóne tréningového zataženia. 




Obr. 5 Komparácia $\mathrm{PH} 25 \times 18$ m s rôznym počtom hráčov

Tab. 4: Komparácia PH s rozmerom $25 \times 18 \mathrm{~m}$ s rozdielnym počtom hráčov

\begin{tabular}{|c|c|c|c|c|c|}
\hline n hráčov & 1. zóna & 2. zóna & 3. zóna & 4. zóna & 5. zóna \\
\hline $2: 2$ & $1,49 \%$ & $8,85 \%$ & $11,48 \%$ & $34,57 \%$ & $43,61 \%$ \\
\hline $3: 3$ & $1,76 \%$ & $6,16 \%$ & $10,74 \%$ & $54,26 \%$ & $27,08 \%$ \\
\hline
\end{tabular}

PH $30 \times 25$ metrov je efektívnejšia z pohl'adu intenzity tréningového zataženia pri menšom počte hráčov $2: 2$. Až $31,16 \%$ času z celkového tréningového zataženia absolvovali hráči v najvyššej zátažovej zóne a v porovnaní s väčším počtom hráčov (3:3) to predstavovalo rozdiel takmer $15 \%$ $\mathrm{z}$ celkového času tréningového zataženia. $\mathrm{V}$ súčte časových úsekov $\mathrm{v}$ dvoch najintenzívnejších zónach však tento rozdiel takmer zanikol. Predstavoval hodnotu len $1,65 \%$ z celkového trvania PH.

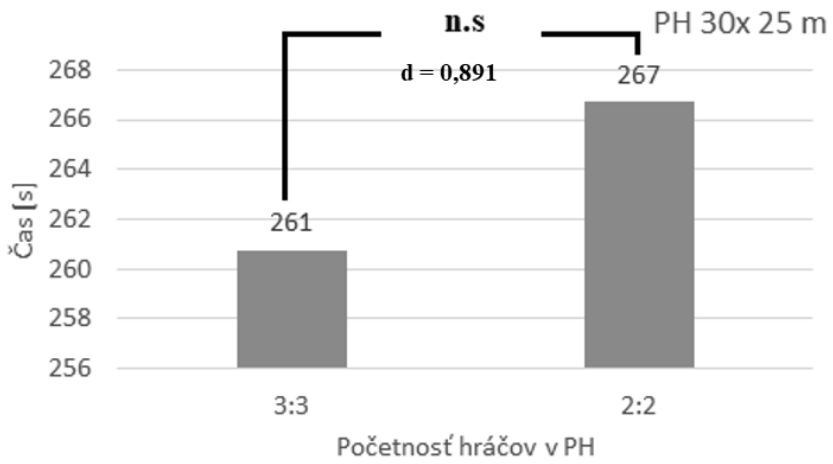

Obr. 6 Komparácia $\mathrm{PH} 25 \times 18$ m s rôznym počtom hráčov

Tab. 5: Komparácia $\mathrm{PH} s$ rozmerom $30 \times 25 \mathrm{~m}$ s rozdielnym počtom hráčov

\begin{tabular}{|c|c|r|r|r|r|}
\hline n hráčov & 1. zóna & 2. zóna & 3. zóna & 4. zóna & 5. zóna \\
\hline $2: 2$ & $1,46 \%$ & $10,24 \%$ & $14,22 \%$ & $42,92 \%$ & $31,16 \%$ \\
\hline $3: 3$ & $1,06 \%$ & $7,31 \%$ & $19,19 \%$ & $56,11 \%$ & $16,32 \%$ \\
\hline
\end{tabular}

Pri hráčoch tejto vekovej kategórie sa ukazuje, že najintenzívnejšia hra (96-100 \% zo SF max) bola PH s menším počtom hráčov $(2: 2)$ s rozmerom ihriska $25 \times 18$ metrov. Pri tomto rozmere a počte hráčov, hráči absolvovali 43,61 \% času celkového tréningového zataženia v zóne 5 (96-100\% zo SF max), čo je približne 314 sekúnd z celkových 720 sekúnd. 
Najkratší časový úsek v zóne 5 (96-100 \% zo SF max) sme zaznamenali v PH s väčším počtom hráčov $(3: 3)$ s rozmerom ihriska $30 \times 25$ metrov. Tento časový úsek predstavoval $16,32 \%$ $\mathrm{z}$ celkového času tréningového zataženia. $V$ absolútnych hodnotách to predstavuje 117,5 sekundy $\mathrm{z}$ celkového času (720 s).

Hráči do 15 rokov najdlhší časový úsek absolvovali v zóne 4 (85-95 \% zo SF max) v PH s väčším počtom hráčov ( $3: 3) \mathrm{s}$ rozmerom ihriska $30 \times 25$ metrov. Táto hodnota predstavuje $56,11 \%$ (404 sek) z celkového času (720 s). Vzhl'adom na to, že v PH 3:3 s väčším rozmerom ihriska $30 \times 25 \mathrm{~m}$ a v PH $3: 3 \mathrm{~s}$ menším rozmerom ihriska $25 \times 18$ metrov je rozdiel v časovom úseku tréningového zataženia v zóne 4 len necelé dve percentá. Môžeme vyslovit záver, že PH 3:3 s menším rozmerom ihriska $25 \times 18$ je intenzivnejšia vzhl’adom na časový úsek, ktorý hráči strávili zóne 5. Najmenej času stráveného v zóne 4 ( $85-95 \%$ zo SF max) bolo v PH 2:2 s rozmerom ihriska $25 \times 18$ metrov $(34,57 \%)$ čo predstavuje 249 sekúnd z celkového času tréningového zataženia (720 s). Za najmenej intenzívnu hru považujeme PH s väčším počtom hráčov (3:3) a s väčším rozmerom ihriska $30 \times 25$ metrov. Pri tejto kombinácii parametrov tréningového podnetu sme zistili, že tréningové zataženie hráčov bolo z časového hl'adiska dlhšie v zóne 3 (74-84 \% zo SF max), ako v zóne 5 (96-100\% zo SF max).

Owen, Twist \& Ford (2004) uvádzajú, že rozdiely v PH s rôznym počtom hráčov a taktiež s rôznymi rozmermi ihriska vplývajú na srdcovú frekvenciu. Snažili sa nájst takú $\mathrm{PH}$, ktorá sa bude svojou intenzitou približovat, alebo bude kopírovat zataženie v zápase. Tvrdia, že PH $1: 1$ a PH

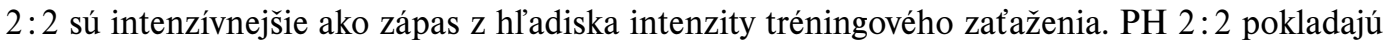
$\mathrm{z}$ hl'adiska intenzity tréningového zataženia za najintenzívnejšiu pri rozmere $25 \times 20$ metrov čo bol približne náš rozmer ihriska $(25 \times 18)$. V tréningovom procese volíme také tréningové prostriedky, ktoré často prekračujú intenzitu v zápase. Je to z dôvodu, aby sa organizmus hráča adaptoval $\mathrm{v}$ tréningu na zataženie $\mathrm{v}$ zápase. Následne ak sa vyskytne $\mathrm{v}$ zápase podnet, ktorý bude svojimi bioenergetickými nárokmi nadštandardný, organizmus hráča bude reagovat primerane adekvátne, pretože sa v tréningovom procese stretol s takým stresorom už opakovane.

Abrantes et al. (2012) analyzovali vnútorné zataženie 15 ročných futbalistov v prípravných hrách s počtom 3:3 a 4:4 a zistili podobné výsledky ako uvádzame v našom výskume, že najdlhšie časové úseky hráči absolvovali v bioenergetických zónach zataženia od 85-90\% z maximálnej srdcovej frekvencie hráčov. U hráčov nášho súboru môžeme taktiež hovorit’ o tom, že sa najčastejšie pohybovali v rozmedzí (85-95\% zo SF max) jedinou výnimkou bola PH 2:2 s rozmerom ihriska $25 \times 18$ metrov. Vo všetkých ostatných hrách sa pohybovali v zóne zataženia na úrovni (85-95\% zo SF max).

Owen et al. (2011) zistili štatisticky významné rozdiely medzi PH s malým počtom hráčov a PH s vel'kým počtom hráčov, z hladiska srdcovej frekvencie. PH s malým počtom hráčov (3:3) indikujú vyššiu úroveň SF v porovnaní s PH s vel'kým počtom hráčov (9:9). Hráči pri PH s malým počtom hráčov mali dlhší časový úsek SF $85-95 \%_{\max }$ a SF $96-100 \%_{\max }$ ako hráči v PH s väčším počtom hráčov. S výsledkami autorov Owen et al. (2011), ktorí tvrdia, že so zvyšujúcim sa počtom hráčov klesá intenzita zataženia sa môžeme stotožnit pri oboch rozmeroch ihriska $(25 \times 18$ metrov, $30 \times 25$ metrov $)$.

Jeden z faktorov, ktoré výrazne ovplyvňujú srdcovú frekvenciu hráčov sú pravidlá. Autori Hill-Haas et al. (2011) poukazujú na zistenie, že aj drobné zmeny pravidiel v prípravných hrách s malým počtom hráčov môžu výrazne ovplyvnit fyziologické, senzorické a motorické pohybové reakcie mladých elitných futbalistov.

Ďalším faktorom, ktorý môže prispiet k intenzifikácii tréningového zataženia by mohla byt motivácia. Autori Rampinini et al. (2007) vo svojej štúdii hovoria o ovplyvňovaní intenzity załaženia $v$ tréningovom procese vplyvom d’alších faktorov ako je koučovanie hráčov počas priebehu tréningového procesu. Zistili, že povzbudzovanie trénera vplýva na intenzitu tréningového załaženia približne siedmimi percentami. 


\section{ZÁVĚRY}

Prípravné hry s rôznymi rozmermi ihriska a aj prípravné hry s rôznym počtom hráčov vyvolali submaximálne a maximálne załaženie, čím sa riadenie tréningového procesu môže stat efektívnym z pohl'adu herného tréningu, ale aj z hl’adiska vývojových tendencií v elitnom mládežníckom futbale.

Ukazuje sa, že je možné pomocou špecifických tréningových podnetov komplexného charakteru za vhodnej organizácie tréningových prostriedkov vyvolat potrebné herné zataženie hráčov v zmysle adekvátneho krytia (z pohladu intenzity, ale aj z pohladu zložitosti tréningového załaženia), napriek tomu, že sa nepotvrdil štatistický významný vztah z našich hypotéz.

Štúdia dokumentuje, že prípravná hra s vyšším počtom hráčov $(3: 3)$ a s menším rozmerom ( $25 \times 18$ metrov) vyvolala u elitných hráčov tejto vekovej kategórie, $\mathrm{z}$ hladiska času stráveného v tažiskových bioenergetických zónach, najväčšiu odozvu.

Tieto poznatky môžu tréneri využit pri riadení a operatívnom plánovaní tréningového procesu. Myslíme si, že podobné tréningové prostriedky môžu napomôct trénerom adekvátne pôsobit s uvedenými tréningovými podnetmi na elitných mládežníckych hráčov v tejto vekovej kategórii. Táto práca je súčastou výskumnej úlohy VEGA 1/0529/16: Účinnost̉ športovej prípravy klubových a reprezentačných basketbalových družstiev v závislosti od veku a pohlavia.

\section{Reference}

Abrantes, C. I., Nunes, M. I., MaÇãs, V. M., Leite, N. M., \& Sampaio, J. E. (2012). Effects of the number of players and game type constraints on heart rate, rating of perceived exertion, and technical actions of small-sided soccer games. The Journal of Strength \& Conditioning Research, 26, 976-981.

Bada, V. (2014). Ako sa dá predchádzat' chorobám srdca a ciev. Praha: Tigis Print.

Benson, R., \& Connolly, D. (2012). Trénink podle srdeční frekvence. Praha: Grada.

Engel, F., Prus, M., \& Vieth, N. (2016). Jugendfußball: Ausbilden mit Konzept 3. Münster: Philippka-Sportverlag.

Gabbett, T. J. (2006). Skill-based conditioning games as an alternative to traditional conditioning for rugby league players. Journal of Strength and Conditioning Research, 20, 309.

Gabbett, T., Jenkins, D., \& Abernethy, B. (2009). Game-based training for improving skill and physical fitness in team sport athletes. International Journal of Sports Science \& Coaching, 4, 273-283.

Gamble, P. (2004). A skill-based conditioning games approach to metabolic conditioning for elite rugby football players. The Journal of Strength Conditioning Research, 18, 491-497.

Gregson, W., \& Drust, B. (2000). The physiology of football drills. Insight; 3(4), 1-2.

Hill-Haas, S. V., Dawson, B., Impellizzeri, F. M., \& Coutts, A. J. (2011). Physiology of small-sided games training in football. Sports medicine, 41(3), 199-220.

Holienka, M. (2005). Kondičný tréning vo futbale. Bratislava: Peter Mačura-PEEM.

Holienka, M. et al. (2012). Tréningové a zápasové zat’aženie hráča v športových hrách. In: Holienka, M. (Ed). Vnútorné zat’aženie organizmu hráčov a jeho odozva v závislosti od hráčskej funkcie vo vybraných športových hrách. Bratislava: ABL PRINT.

Little, T. (2009). Optimizing the use of soccer drills for physiological development. Strength \& Conditioning Journal, 31(3), 67-74.Peráček, P. (2001). Futbal: riadenie, plánovanie, tréning. 3. vyd. Bratislava: Peter Mačura-PEEM.

Owen, A. (2003). Physiological and technical analysis of small-sided conditioned training games within professional football. Wrexham: SAGE Publications.

Owen, A., Twist, C., \& Ford, P. (2004). Small-sided games: the physiological and technical effect of altering pitch size and player numbers. Insight, 7(2), 50-53.

Owen, A. L., Wong, D. P., McKenna, M., \& Dellal, A. (2011). Heart rate responses and technical comparison between smallvs. large-sided games in elite professional soccer. The Journal of Strength \& Conditioning Research, 25(8), 2104-2110.

Peráček, P. (2003). Športové hry. Bratislava: Peter Mačura-PEEM.

Peráček, P. (2004). Teória a didaktika športových hier I. Bratislava: Peter Mačura-PEEM

Peráček, P. \& Pakusza, Zs. (2011). Futbal. Bratislava: IRIS.

Rampinini, E., Impellizzeri, F. M., Castagna, C., Abt, G., Chamari, K., Sassi, A., \& Marcora, S. M. (2007). Factors influencing physiological responses to small-sided soccer games. Journal of sports sciences, 25(6), 659-666.

Vilímová, V. (2002). Didaktika tělesné výchovy. 1. vyd. Brno: Paido. 